\title{
理事に就任して
}

低温工学協会理事／住友重機械工業株式会社

\section{小泉 鎚雄}

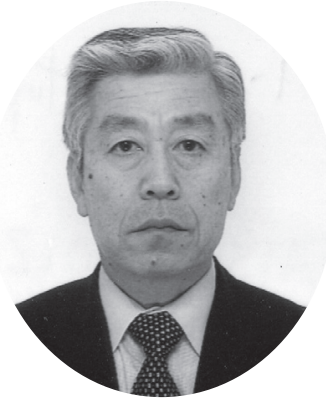

極低温との関わりを振り返ってみますと， 入社以来，極 低温冷凍機の開発から商品化及び事業化に携わってきま した。最初は, 磁気浮上列車用車載冷凍機の開発で, 東芝 殿と共同で小型クロード式冷凍機を開発し，膨張エンジン の低温部にある自動弁の信頼性に苦労したことを記憶して おります。また，宮崎実験線での走行試験の苦労も今とな れば大変懐かしく思われます。現在は, 山梨実験線にて車 載冷凍機は $\mathrm{GM}+\mathrm{JT}$ 冷凍機が搭載され, 実用化に向けて 走行試験が継続されています。その後, クライオポンプ用 $\mathrm{GM}$ 冷凍機の商品化, 続いて, $4 \mathrm{~K}$ で数 W の冷凍能力を 有する $\mathrm{GM}+\mathrm{JT}$ 冷凍機の商品化を行い, 国立天文台野辺 山宇宙電波観測所のアンテナに初めて搭載し観測に活用し ていただきました。この頃は, 冷凍機の信頼性が豆しくて, 度々現地に赴き冷凍機の調整及び修復をしたことを覚えて おります。

画期的な出来事は，磁性蓄冷材を用いた $4 \mathrm{KGM}$ 冷凍機 が東芝殿, 三菱電機殿から相次いで発表されたことです。 各社も追随して研究開発が活発に行われ研究発表も活況が ありました。4KGM 冷凍機の実現は，小型かつ簡易な操作 で $4 \mathrm{~K}$ を得ることができる冷却技術を生み出したことで， 冷凍機の用途を飛躍的に拡大させました。幸い，当社は才 リジナルな技術を生かして，信頼性の高い 4KGM 冷凍機 を開発することができ，世界の MRI メーカーに採用して いただき，グローバルに展開をしております。極低温冷凍 機は, 当初の実験室規模では, 性能に重きがおかれ, 運転 操作は経験者が行うなど複雑な機械でも使われましたが, 信頼性に乏しく，産業分野への展開は進夕ませんでした。 一方, クライオポンプは産業用として使用されてますが, 信頼性の点では，まだまだ不十分だと思います。したがっ て，極低温冷凍機が産業用として発展するためには，ユー ザが安心して使用できる「信頼性」が高い冷凍機でなけれ ばなりません。冷凍機は, 冷却する手段であり，ユーザに とっては, 低温が維持できれば良いのです。もちろん, 冷 凍機に付加価值があればそれに優ることはありません。
現在, 各研究機関, 大学, 企業において次世代の極低温 冷凍機の開発が行われていますが，その成果が，実用化さ れるためには, VOC (Voice of customer) を十分に把握 して実行することが重要と思います。聞くところによれば, 液体ヘリウムの消費は増大しているようです。しかしなが ら, 液体へリウムは有限資源ですので, 消費が増え続けれ ば価格の高騰が予想され, 益々, 信頼性の高い冷凍機への 実現が期待されて，超電導・低温技術市場の拡大に繫がる と確信します。

一方，超電導及び低温技術の市場はニッチです。古く から期待された技術・市場でありますが，伸び悩んでおり， 超電導・低温技術に関する研究・開発費は一時期より大幅 に減少し, 特に, 企業では, 近年の経済情勢の変化の中で, 研究・開発人口は大幅に減少しており, 市場動向を読めず 暗中模索をしている段階と思います。産業界, 企業が元気 を取り戻すためにも, 将来の市場動向, 技術動向などを把 握できる情報の提供, また, 新たな市場を創出する手がか りの提供などの役割を低温工学協会が取り組み, 産業化の 役に立つことが望まれているのではないでしょか。

とにかく, 超電導及び低温技術の市場が拡大され, 多く の企業がビジネスに参画できれば，これらの産業は活性化 し, 好循環が生まれて, 低温工学協会も活況を呈すること になるかと思います。

現在, 低温工学協会は大きな課題に直面しております。 産業界からの賛助会員減少, 研究者・技術者会員の減少が おきており，このままでは産業界及び協会の発展も危ぶま れます。この危機的状況を回避するために, 山藤協会長が, 「研究・開発の活性化と協会の活性化をみんなの力で成し遂 げよう」と呼びかけ，「基盤強化・活性化事業準備委員会」 が設置され, 協会を活性化する事業の企画・立案活動が実 行されております。小職も産業界の一員として, 超電導及 び低温技術の発展と低温工学協会の活性化に向けて尽力致 す所存です。 